\title{
Factors associated with cocaine smoking in students at Santa Marta, Colombia
}

\section{Factores asociados a consumo de cocaína en estudiantes en Santa Marta, Colombia}

\author{
Adalberto Campo-Arias ${ }^{1}{ }^{\circ}$, Remedios Milagros Daza-Fragozo ${ }^{1}$,Carmen Cecilia Caballero-Domíngez ${ }^{1}{ }^{*}$ \\ ${ }^{1}$ Universidad de Magdalena, Santa Marta, Colombia \\ *Dirigir correspondencia a: acampoa@unimagdalena.edu.co
}

\begin{abstract}
Background: Cocaine smoking is in the second place of illegal substance use among Colombian adolescents; however, there is little information about its associated

Article History

Received: 300820

Accepted: 171220

Published:15 0221

DOI 10.17081/innosa.113

CCopyright2021.

Campo-Arias ${ }^{1}$ et al.

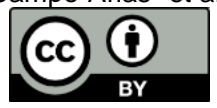

factors. Methods: A cross-sectional study was designed for which participated in highschool students between 13 and 17 years. Crude and adjusted associations were calculated for cocaine smoking. Results: A group of 1,462 adolescent students $(M=14.4$ years, $S D=0.8$ ) participated in the research, $60.3 \%$ were females, and $55.3 \%$ studied in the tenth grade. A total of 40 students $(2.7 \%)$ reported lifetime cocaine smoking. Cocaine smoking was associated with lifetime cannabis smoking (OR=8.34, $95 \% \mathrm{Cl} 3.70-18.80)$, lifetime cigarette smoking (OR=7.96, 95\% $\mathrm{Cl} 2.96-21.43)$, risk of post-traumatic stress disorder $(\mathrm{OR}=2.43,95 \% \mathrm{Cl} 1.20-4.95)$, and studying in the tenth grade $(\mathrm{OR}=2.38,95 \% \mathrm{Cl} 1.14-4.98)$. Conclusions: Cannabis and cigarette smoking are the main variables associated with lifetime cocaine smoking among high-school adolescents from Santa Marta, Colombia. It is necessary to explore other factors associated with cocaine smoking in adolescent students

Keywords: Cocaine smoking; risk factors; adolescents; students; cross-sectional studies.

\section{INTRODUCTION}

In the global context, abuse and dependence on legal and illegal substances represent a problem determined by the state of health, family relationships, academic or work performance, citizen coexistence, and the countries' economy (1). Substance use, abuse, and dependence have grown gradually in recent decades (2). Usually, the consumption of legal and illegal substances begins in adolescence or the first years of adult life (ㅁ) .

About the lifetime prevalence of cocaine smoking among adolescence, the 2015 National Mental Health Survey omitted the information on the prevalence of consumption of this illegal substance (4). However, some studies show that cocaine smoking is in the second place of illegal substance use in Colombian adolescents, after cannabis smoking, and its lifetime prevalence varies between 1.4 and $6.6 \%$ (ㅁ-ㄱ).
\end{abstract}


Like other substances, the initiation and maintenance of cocaine smoking is a complex issue related to several personal and contextual biological and environmental factors $(\underline{1}, \underline{3})$. Some factors include a) biological and individual factors such as age, gender, general health condition, and b) contextual variables such as family environment, exposure to violence, symptoms or depressive disorders, and consumption of legal substances and other substances illegal like cannabis $(\underline{1}-\underline{3}, \underline{8})$.

Cocaine smoking is a significant concern because it produces symptoms that can be fatal during poisoning, such as changes in heart rate and blood pressure, cardiac arrhythmias, respiratory depression, confusion, and seizures (9). Besides, cocaine smoking is frequently associated with health risk behaviors, for instance, unprotected sex (10), and criminal acts or transgressions of different levels of social impact, such as fighting or robbery, either as a strategy to get the money to buy to maintain or to the cognitive changes associated with consumption (11).

Therefore, preventive strategies and early identification of cocaine smoking in adolescents in the school context are highly relevant in public health (12). This study explores a set of variables previously omitted from previous research concerning cocaine smoking in adolescent students in the Colombian Caribbean.

The present study's objective was to explore some factors associated with lifetime cocaine smoking among high-school adolescents at Santa Marta, Colombia.

\section{METHODS}

\subsection{Study design}

An observational, analytical, cross-sectional study was carried out.

\subsection{Population, and sample size and protocol}

For the sample calculation, it was considered that for the year 2016, 10,810 students were enrolled in high school grades in Santa Marta, public and private institutions. A multistage probabilistic cluster sampling was designed. Each classroom was taken as a conglomerate, and each one would be made up of 25 students on average. Given expected frequencies of different measured variables, the appropriate sample size was calculated for frequencies as low as $1 \%$ (margin of error of 1 ) and as high as $50 \%$ (margin of error of 5 ), with a confidence level of $95 \%$. A sample of 384 participants was acceptable (13). However, the authors preferred to multiply the initial estimate by four to facilitate the estimation of associations with narrower confidence intervals. Likewise, the replacement of $25 \%$ was included considering the possible loss of participants, for example, due to the institution's refusal, not having the informed tutor consent, nor students assent. With the descriptive parameters, the participation of 1,948 students was requested. Only tenth and eleventh-grade students aged between 13 and 17 years were included. Students with a disability to independently complete the questionnaire were excluded. 


\subsection{Measurements}

The research questionnaire asked for demographic variables such as age, gender, education level, and socioeconomic status. The ages were categorized into two groups, the first being between 13 and 15 years old and the second between 16 and 17. Likewise, it was investigated the last-month self-perception of academic performance, perception of general health, family functioning, risk of post-traumatic stress disorder, risk of a major depressive episode (MDE), and lifetime school bullying, alcohol drinking, cigarette smoking, cannabis consumption, and cocaine smoking.

The self-perception of academic performance and perception of general health were evaluated with a single item taken from the Questionnaire of Epidemiological Surveillance of Psychoactive Substances, VESPA, widely used in Colombia (14). These items have an excellent, good, fair, and poor ordinal response pattern. For this analysis, the four response options were dichotomized into excellent-good and fair-poor.

Lifetime school bullying and substance use (alcohol, cigarette, cannabis, and cocaine) were assessed with items taken from the Youth Risk Behavior Survey Questionnaire for Middleschool students of the United States Center for Disease Control. These items have a simple response pattern, yes or no (15). The Youth Risk Behavior Survey Questionnaire has shown high reproducibility in previous studies (16).

Family functioning was quantified with the family APGAR. The family APGAR has five items that measure adaptability, cooperation, growth, affectivity, and resolving capacity. Each item presents five response options: never, seldom, sometimes, almost always, and always. Such responses are rated in ascending order from zero to four. Thus, the total scores are observed between zero and twenty (17). In the present investigation, those scores between 0 and 15 were categorized as family dysfunction. This instrument showed high internal consistency in the Colombian adolescents' group, Cronbach's alpha of 0.79 (18). In this sample of students, the family APGAR presented Cronbach's alpha of 0.82 .

The risk of post-traumatic stress disorder (PTSD) was measured with the short, four-item version of the Brief Davidson Trauma Scale (BDTS). This instrument explores the presence of hyper-alertness, physiological excitement, anger, and mental dullness of post-traumatic stress disorder. Each item offers four possible responses to which one to four points are assigned. Consequently, the total scores are in the range between 4 and 16. In the current investigation, those scores greater than 12 were categorized as high risk of PTSD (19). The large version of the scale presented acceptable consistency in a previous study with Colombian adults, with Cronbach's alpha $0.97(\underline{20})$. In the sample of the present study, Cronbach's alpha was 0.66.

The risk of an MDE was established with the application of the Well-Being Index (WHO-5). This index quantifies general well-being or the absence of depressive symptoms during the last two (21). The WHO-5 brings together five items that address mood, tranquility, energy level, quality of sleep, and daily life enjoyment. Each item presents four options that are rated from one to four. Total scores are between five and twenty. For the current research, scores lower than nine were categorized as the risk of an MDE. The WHO- 5 showed Cronbach's alpha of 0.70 in 
another study in adolescents from the Colombian Caribbean (22). In the current sample, Cronbach's alpha was 0.82 .

\subsection{Procedure}

The collection of information began with presenting the research objectives, delivering the selfadministered questionnaire to the students who brought the informed consent, previously sent to the students' parents or legal guardians. In the classroom, the students who agreed to participate complete the research questionnaire supervised by a field team member. The participation was utterly anonymous. Data collection was carried out between September and October 2018.

\subsection{Analysis of data}

The descriptive component explored frequencies, percentages, mean (M), and standard deviation (SD). To establish the association between independent variables and lifetime cocaine smoking was computed odds ratios (OR) with $95 \%$ confidence intervals $(95 \% \mathrm{Cl})$. Those variables that showed probability values less than $25 \%$ were considered for the final adjustment. The goodness of fit was calculated with the Hosmer-Lemeshow's test for the adjusted variables. Those that showed $95 \% \mathrm{Cl}$ that did not include the unit were accepted as significant associations. The analysis was completed in IBM-SPSS, version 23.0.

\subsection{Ethical issues}

This investigation included the review and approval of a Research Ethics Committee in Santa Marta, Colombia. Parents signed informed consent and students assent to participate.

\section{RESULTS}

\subsection{Sample description}

A total of 1,462 students participated in the research. Four-hundred eighty-six students than expected $(24.9 \%)$ participated because several selected schools refused to participate, the classrooms had fewer students than the estimated average, or the students did not bring informed consent from their parents. The ages were observed between 13 and 17 years, $M=14.4$ years $(S D=0.8)$. The frequencies and percentages for each variable are shown in Table 1. Regarding lifetime cocaine smoking, 40 students (2.7\%) answered affirmatively, and 1,442 $(97.3 \%)$ denied having ever used it in their life.

\subsection{Crude and adjusted association}

Statistically significant associations with cocaine smoking were observed between health perception, risk of PTSD, risk of MDE, and lifetime consumption of alcohol, cigarette, and cannabis. See table 2. 
Table 1. Characteristics of the students.

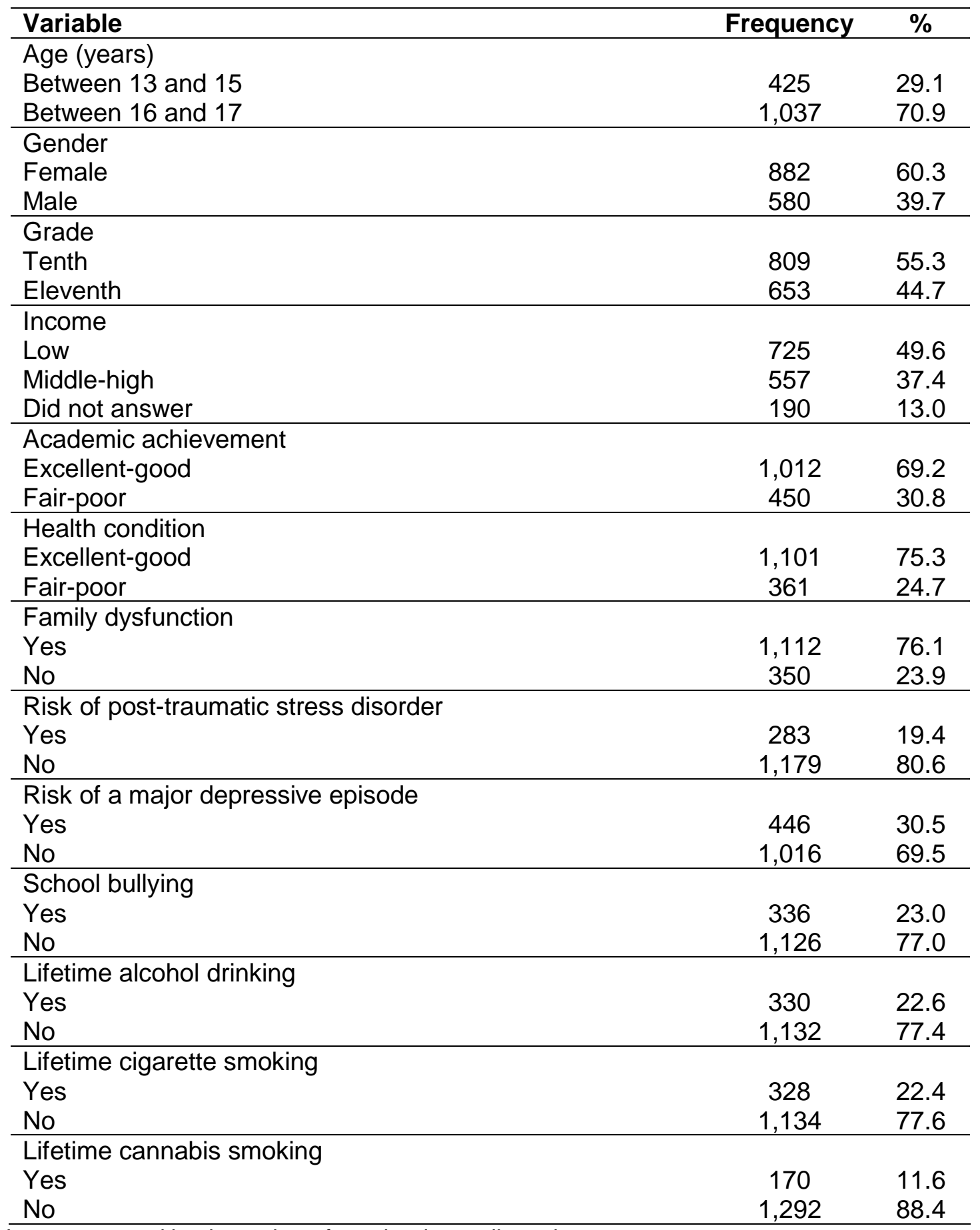

Source: It was prepared by the authors from the data collected. 
Table 2. Factors associated with lifetime cocaine smoking in students from Santa Marta, Colombia

\begin{tabular}{lcc}
\hline Variable & OR & CI95\% \\
\hline Age 13-15 years & 1.05 & $0.53-2.08$ \\
Female gender & 1.55 & $0.78-3.08$ \\
Tenth grade & 1.92 & $0.97-3.80$ \\
Low income* & 1.04 & $0.73-1.48$ \\
Fair-poor academic achievement & 1.88 & $0.99-3.53$ \\
Fair-poor health condition & 2.32 & $1.22-4.38$ \\
Family dysfunction & 0.94 & $0.46-1.95$ \\
Risk of post-traumatic stress disorder & 3.21 & $1.69-6.10$ \\
Risk of a major depressive episode & 2.34 & $1.25-4.39$ \\
School bullying & 1.64 & $0.84-3.21$ \\
Lifetime alcohol drinking & 5.70 & $1.37-23.74$ \\
Lifetime cigarette smoking & 21.74 & $9.04-52.28$ \\
Lifetime cannabis use & 23.95 & $11.71-48.99$ \\
\hline
\end{tabular}

${ }^{*}$ Compared to middle-high, not including missing data.

Source: It was prepared by the authors from the data collected.

For the final adjustment, grade and self-perception of academic performance that showed probability values of less than $25 \%$ were considered. The best-fitting model showed descending order that cannabis use, cigarette smoking, risk of PTSD, and studying in the tenth grade were significantly associated with lifetime cocaine smoking. See table 3.

Table 3. Adjusted model for factors associated with cocaine smoking in high-school students from Santa Marta, Colombia

\begin{tabular}{lcc}
\hline Variable & OR & Cl95\% \\
\hline Lifetime cannabis smoking & 8.34 & $3.70-18.80$ \\
Lifetime cigarette smoking & 7.96 & $2.96-21.43$ \\
Risk of post-traumatic stress disorder & 2.43 & $1.20-4.95$ \\
Tenth grade & 2.38 & $1.14-4.98$ \\
\hline
\end{tabular}

Hosmer-Lemeshow test $=4.07, \mathrm{df}=4, \mathrm{p}=0.40$.

Source: It was prepared by the authors from the data collected.

\section{DISCUSSION}

In the present study, it is observed that lifetime cigarette and cannabis smoking, risk of PTSD, and studying tenth grade were significantly associated with lifetime cocaine smoking among high-school adolescents in Santa Marta, Colombia.

The association between the level of schooling and cocaine smoking has not been observed in previous studies. However, Espinosa et al. (15) and Manrique-Abril et al. (23) did not observe statistically significant differences between the tenth and eleventh-grade students from Cali and Tunja, Colombia. Likewise, Maldonado et al. (24) found a similar prevalence of cocaine smoking in students of the last two years of high school in Lima, Peru. 
In the present analysis, it was shown that the risk of PTSD was associated with cocaine smoking. This finding is consistent with studies in other countries. For example, Flores et al. (25), in Mexican American adolescents, observed that they experienced marked symptoms of PTSD correlated with the consumption of illegal substances, cannabis, and cocaine, among others. Similarly, Schiff et al. (26), in Arab and Jewish middle-school adolescents, observed that scores for post-traumatic stress were associated with cannabis use and ecstasy during the last year.

In the current study, cigarette smoking was related to cocaine smoking. Similar to the association observed by Cogollo et al. (ㅇ), these researchers showed that current smoking increased the frequency of consumption of illicit substances in Colombian adolescents, and Céline et al. (27) reported that lifetime cigarette smoking was associated with cocaine smoking in French adolescents. In the same sense, longitudinal studies showed a similar association. Keyes et al. (28), in the United States in high-school students, observed that the prevalence of cigarette smoking in eighth and tenth grades was associated with the prevalence of cocaine smoking in twelfth grade. Nkansah-Amankra (29) showed that lifetime cigarette smoking in early adolescence predicted (between 1 and 19 times) cocaine smoking in late adolescence in middle- and high-school students in the United States. However, do Nascimento et al. (30) reported independence between tobacco and lifetime cocaine smoking in adolescent students at Penabumco, Brazil.

In the present analysis, it was observed that cannabis use was associated with cocaine smoking. This observation is consistent with Céline et al. (27), who found that cannabis smoking was significantly associated with lifetime cocaine smoking. However, Nkansah-Amankra (29) ), in the study mentioned above, observed that lifetime cannabis smoking in early adolescence did not predict cocaine smoking in late adolescence.

The similarities and differences observed in this study's findings with the previous studies may lie in the study designs, cross-sectional and longitudinal, the disparities in the social and cultural contexts, the form of measurement of the variables of interest, and the years of carrying out the studies. It is essential to unify criteria for the measurement and monitoring of substance use in adolescents and adults. This strategy would allow better comparisons and interpretation of the findings in the different contexts (31). Convoluted health problems such as cocaine smoking require permanent reviews of the prevalence and associated variables according to the determinants of health for each community; the findings of particular contexts can be rarely generalized to the world population, beyond the world increasingly globalized (2).

The prevention of cocaine smoking requires comprehensive and integrated strategies and actions (12). Cocaine smoking is a problem in which converges individual, medial and structural determinants (1- $\underline{3})$. However, professionals must pay particular attention to the prevention of legal substance use such as alcohol and cigarettes, which often serve as a gateway to illegal substances such as cannabis and cocaine; it is a phenomenon of escalating consumption. It is common since legal to illegal substances or those of lesser potency to higher potency in the effect or possibility of inducing dependency (29). In the present study, specific cultural variables that qualify substance use in adolescents, such as sexist cultural patterns or familism, were not quantified. Measurement of these cultural variables has increased in epidemiological studies; 
however, the difficulty of objectifying the evaluation of collective attitudes, beliefs, and practices (2).

The current study contributes to knowledge because presenting the variables associated exclusively with lifetime cocaine smoking due to the low prevalence in previous studies, and they had not been analyzed in a disaggregated way of other illegal substances. However, this research has the limitation of cross-sectional studies that prevent establishing the association's direction unequivocally. Besides, the number of students who reported cocaine smoking at some time in their lives was low, and, therefore, they are observed wide confidence intervals in some associations. There is a risk of type II error for other explored associations (13).

\section{CONCLUSIONS}

It is concluded that lifetime cigarette and cannabis smoking, the risk of PTSD, and the tenth grade are associated with lifetime cocaine smoking among high-school adolescents at Santa Marta, Colombia. It is necessary to know how to explore other factors associated with cocaine smoking in middle school students.

Author contribution: Adalberto Campo-Arias: Conceptualization, content and data curation, formal data analysis, acquisition of funds, research, methodology, project management, material resources, software, supervision, visualization, and revision and editing. Remedios Milagros Daza-Fragozo: Conceptualization, content and data curation, software, visualization, draft writing, and revision and editing. Carmen Cecilia Caballero-Domínguez: Conceptualization, acquisition of funds, research, supervision, validation, visualization, and revision and editing.

Funding: The Research Vice-Rectory of the University of Magdalena financed this work through Resolution 0347 of 2018 (Fonciencias Call for Proposals 2017).

Acknowledgments: Our gratitude for the invaluable cooperation in the process of collecting information for the research assistant psychology students: Adriana Rodríguez Martínez, Ana Celis Márquez, Carlos Fuentes López, Daniela Gonzales Cantillo, Heiner Tordecilla Arroyo, Nataly Tapia Duarte, Sandra Gómez Mariscal, and Yuleinys Dávila Gómez. Also, we want to thank to the support psychology professionals: Amparo Echeverry Arias, Heigui Araújo Zúñiga, Johana Guerrero Bolaño, and María Paola Jiménez Villamizar.

Conflict of interest: Nothing to declare.

\section{REFERENCES}

1. Medina-Mora ME, Real T, Villatoro J, Natera G. Las drogas y la salud pública: ¿hacia dónde vamos? Salud Publica Mex. 2013; 55: 67-73. http://www.scielo.org.mx/scielo.php?script=sci arttext\&pid=S0036-36342013000100010

2. Yi-Mak K, Harrison L. Globalisation, cultural change and the modern drug epidemics: the case of Hong Kong. Health Risk Soc. 2001; 3: 39-57. DOI: 10.1080/713670177

3. Mendoza YL, Vargas K. Factores psicosociales asociados al consumo y adicción a sustancias psicoactivas. Rev Electr Psicol Iztacala. 2017; 20: 139-167. https://www.medigraphic.com/pdfs/epsicologia/epi-2017/epi171h.pdf 
4. Encuesta Nacional de Salud Mental 2015. Bogotá: Ministerio de Salud-Colciencias; 2015.

5. Zapata MA, Segura AM. Consumo de drogas y riesgos asociados en jóvenes escolarizados de la Ciudad de Medellín. 2007. Rev Salud Pública Medellín; 2008; 3: 7-20. https://www.medellin.gov.co/irj/go/km/docs/wpccontent/Sites/Subportal\%20del\%20Ciudadano/ Salud/Secciones/Plantillas\%20Gen\%C3\%A9ricas/Documentos/2012/Revista\%20Salud/Revist a\%20Vol.\%203\%20N\%C2\%B0\%202/1.\%20Consumo\%20de\%20drogas\%20y\%20riesgos\%20 asociados.pdf

6. Rueda-Jaimes GE, Camacho PA, Rangel-Martínez-Villalba AM, Duarte E. Prevalencia del consumo de sustancias en estudiantes de secundaria de Bucaramanga (Colombia) y su área metropolitana. Rev Colomb Psiquiat. 2008; 206. http://www.scielo.org.co/pdf/rcp/v37n2/v37n2a05.pdf

7. Zárate AE, Prada DMC, Padilla SL, Rueda-Jaimes GE. Prevalencia del consumo de sustancias en estudiantes de bachillerato de Pamplona. Colombia: una comparación por género. MedUNAB. 2009; 12: 7-13. https://revistas.unab.edu.co/index.php/medunab/article/view/44

8. Cogollo Z, Gómez EM. Prevalencia de vida de consumo de sustancias en adolescentes de Cartagena, Colombia. Inv Educ Enferm. 2012; 30: 224-230. https://www.redalyc.org/articulo.oa?id=105224306007

9. Zimmerman JL. Cocaine intoxication. Crit Care Clin. 2012; 28: 517-526. DOl: 10.1016/i.ccc.2012.07.003

10. Mondragón LE, Velasco PW, Bonilla Cl. Caracterización del consumo de sustancias y su asociación con otras variables psicológicas. Vertientes. 2018; 20: 49-60. https://www.medigraphic.com/cgi-bin/new/resumen.cgi?IDARTICULO=82572

11. Chavarriaga MC, Segura AM. Consumo de sustancias psicoactivas y comportamientos violentos en estudiantes de 11 a 18 años. Itagüí, Colombia. Rev Salud Pública. 2015; 17: 655-666. https://www.redalyc.org/articulo.oa?id=42243628001

12. Bedoya MA. La lucha contra las drogas: fracaso de una guerra, comienzo de una nueva política. Drugs Addict Behav. 2016; 1: 237-254. https://core.ac.uk/download/pdf/268189608.pdf

13. Hernández J. Selección del tamaño de muestra en estudios clínicos. Rev Colomb Gastroenterol. 2006; 21: 118-121. http://www.scielo.org.co/scielo.php?script=sci arttext\&pid=S012099572006000200010

14. Torres $\mathrm{Y}$, Muñoz AL, Ramírez H. Vigilancia epidemiológica sobre el uso indebido de sustancias psicoactivas “VESPA" Medellín, Antioquia 1992. Bol Epidemiol Antioquia. 1994; 19:180-193.

15. Kann L. Youth risk behavior surveillance-United States, 2015. MMWR. 2016; 65: 1-174.

16. Brener ND, Kann L, McManus T, Kinchen SA, Sundberg EC, Ross JG. Reliability of the 1999 youth risk behavior survey questionnaire. J Adolesc Health. 2002; 31: 336-342. DOI: 10.1016/S1054-139X(02)00339-7

17. Smilkstein G. The family APGAR: A proposal for a family function test and its uses by physicians. J Fam Pract. 1978; 6: 12-31.

18. Forero LM, Avendaño MC, Duarte ZJ, Campo-Arias A. Consistencia interna y análisis de factores de la escala APGAR para evaluar el funcionamiento familiar en estudiantes de básica $\begin{array}{llllll}\text { secundaria. } & \text { Rev } & \text { Colomb } & \text { Psiquiatr. }\end{array}$ http://www.scielo.org.co/scielo.php?pid=S0034$74502006000100003 \&$ script $=$ sci abstract\&tlng=es

19. Davidson JRT. Davidson Trauma Scale. North Tonawanda: The Multi-Health Systems Inc., 1996.

20. Pineda DA, Guerrero OL, Pinilla ML, Estupiñán M. Utilidad de un cuestionario para rastreo del estrés postraumático en una población colombiana. Acta Neurol Colomb. 2002; 18: 132-138. DOI: $10.33588 / \mathrm{rn} .3410 .2002009$

21. World Health Organization. Regional Office for Europe. Well-being measures in primary health care: The DepCare Project. Consensus meeting, Stockholm; 1998. https://www.euro.who.int/ data/assets/pdf file/0016/130750/E60246.pdf 
22. Campo-Arias A, Miranda-Tapia GA, Cogollo Z, Herazo E. Reproducibilidad del Índice de Bienestar General (WHO-5 WBI) en adolescentes estudiantes. Salud Uninorte. 2015; 31: 18-24. http://rcientificas.uninorte.edu.co/index.php/salud/article/viewArticle/5493

23. Manrique-Abril FG, Ospina JM, Herrera GM. Consumo de sustancias psicoactivas y factores determinantes en adolescentes de la ciudad de Tunja 2009. Tunja: UPTC-Secretaría de Protección Social de Tunja; 2009. http://agenf.org/ojs/index.php/shs/article/view/126

24. Maldonado V, da Costa $M$. Consumo de drogas ilegales en escolares y la relación con el entorno. SMAD. 2016; 12: 3-11. DOI: 10.11606/issn.1806-6976.v12i1p3-11

25. Flores E, Tschann JM, Dimas JM, Pasch LA, de Groat CL. Perceived racial/ethnic discrimination, post-traumatic stress symptoms, and health risk behaviors among Mexican American adolescents. J Counsel Psychol. 2010; 57: 264-273. DOI: 10.1037/a0020026

26. Schiff M, Pat-Horenczyk R, Benbenishty R, Brom D, Baum N, Astor RA. High school students' post-traumatic symptoms, substance abuse, and involvement in violence in the aftermath of war. Soc Sci Med. 2012; 75: 1321-1328. DOI: 10.1016/i.socscimed.2012.05.010

27. Céline B, François B, Stanislas S. Physical and psychosocial factors associated with psychostimulant use in a nationally representative sample of French adolescents: Specificities of cocaine, amphetamine, and ecstasy use. Addict Behav. 2019; 92: 208-224. DOl: 10.1016/i.addbeh.2018.11.046

28. Keyes KM, Hamilton A, Kandel DB. Birth cohorts analysis of adolescent cigarette smoking and subsequent marijuana and cocaine use. Am J Public Health. 2016; 106: 1143-1149. DOI: 10.2105/AJPH.2016.303128

29. Nkansah-Amankra S. Revisiting the association between "gateway hypothesis" of early drug use and drug use progression: A cohort analysis of peer influences on drug use progression among a population cohort. Substance Use Misuse. 2000. DOl: 10.1080/10826084.2020.1720245

30. do Nascimento L, da Cruz J, de Santana BW, Campos A, Soares V. Uso de tabaco e outras drogas pelos adolescentes de escolas públicas de Pernambuco: um estudo piloto. Adolesc $\begin{array}{llll}\text { Saude. } & 2018 ; & 15 & \text { 52): }\end{array}$ http://adolescenciaesaude.com/detalhe artigo.asp?id=733\&idioma=Espanhol

31. Hernández-Ávila M, Garrido F, Salazar-Martínez E. Sesgos en estudios epidemiológicos. Salud Publica Mex 2000; 42 (5): 438-446. https://www.scielosp.org/article/spm/2000.v42n5/438446/es/ 